\title{
Article
}

\section{Seasonal and Age-Associated Pathogen Distribution in Newborn Calves with Diarrhea Admitted to ICU}

\author{
Engin Berber ${ }^{1,2, *}{ }^{-}$, Nurettin Çanakoğlu $\left.{ }^{3}{ }^{(}\right)$, İbrahim Sözdutmaz ${ }^{1}$, Emrah Simsek $^{4}$, Neslihan Sursal ${ }^{5}$, \\ Gencay Ekinci ${ }^{6}{ }^{\circ}$, Serkan Kökkaya ${ }^{1,7}{ }^{\circ}$, Ebru Arıkan ${ }^{1}$, Pınar Ambarcıoğlu ${ }^{8}$, Ayşe Gençay Göksu ${ }^{1}$ \\ and İhsan Keleş ${ }^{6}$
}

Citation: Berber, E.; Çanakoğlu, N.; Sözdutmaz, İ.; Simsek, E.; Sursal, N.; Ekinci, G.; Kökkaya, S.; Arıkan, E.; Ambarcıoğlu, P.; Göksu, A.G.; et al. Seasonal and Age-Associated Pathogen Distribution in Newborn Calves with Diarrhea Admitted to ICU. Vet. Sci. 2021, 8, 128. https:// doi.org/10.3390/vetsci8070128

\section{Academic Editors:}

David Longbottom and

Burim Ametaj

Received: 18 March 2021

Accepted: 7 July 2021

Published: 9 July 2021

Publisher's Note: MDPI stays neutral with regard to jurisdictional claims in published maps and institutional affiliations.

Copyright: (C) 2021 by the authors Licensee MDPI, Basel, Switzerland. This article is an open access article distributed under the terms and conditions of the Creative Commons Attribution (CC BY) license (https:/ / creativecommons.org/licenses/by/ $4.0 /)$.
1 Department of Virology, Faculty of Veterinary Medicine, Erciyes University, Kayseri 38280, Turkey; isozdutmaz@erciyes.edu.tr (İ.S.); serkan.kokkaya@yobu.edu.tr (S.K.); ebruarikan05@gmail.com (E.A.); agencay@erciyes.edu.tr (A.G.G.)

2 Department of Biomedical and Diagnostic Sciences, College of Veterinary Medicine, University of Tennessee, Knoxville, TN 37996, USA

3 Department of Virology, Milas Faculty of Veterinary Science, Muğla Sitkı Koçman University, Muğla 48200, Turkey; nurettincanakoglu@mu.edu.tr

4 Department of Preclinical Science, Faculty of Veterinary Medicine, Erciyes University, Kayseri 38280, Turkey; emrahsimsek@erciyes.edu.tr

5 Department of Parasitology, Faculty of Veterinary Medicine, Aksaray University, Aksaray 68100, Turkey; neslihansursal@aksaray.edu.tr

6 Department of Internal Medicine, Faculty of Veterinary Medicine, Erciyes University, Kayseri 38280, Turkey; gekinci@erciyes.edu.tr (G.E.); ihsankeles@erciyes.edu.tr (İ.K.)

7 Department of Microbiology, Faculty of Veterinary Medicine, Bozok University, Yozgat 66700, Turkey

8 Department of Biostatistics, Faculty of Veterinary Medicine, Hatay Mustafa Kemal University,

Hatay 3106, Turkey; kpambarcioglu@mku.edu.tr

* Correspondence: eberber@utk.edu; Tel.: +1-865-249-5855

\begin{abstract}
Calf mortality constitutes a substantial loss for agriculture economy-based countries and is also a significant herd problem in developed countries. However, the occurrence and frequency of responsible gastro-intestinal (GI) pathogens in severe newborn diarrhea is still not well known. We aimed to determine the seasonal and age-associated pathogen distribution of severe diarrhea in newborn calves admitted to the intensive care unit (ICU) of Erciyes University animal hospital over a year. Fecal samples were collected during the ICU admissions, and specimens were subjected to a diarrheal pathogen screening panel that included bovine coronavirus (BCoV), Cryptosporidium spp., ETEC K99+, and bovine rotavirus, using RT-PCR and conventional PCR methods. Further isolation experiments were performed with permissive cell cultures and bacterial enrichment methods to identify the clinical importance of infectious pathogen shedding in the ICU. Among the hospitalized calves aged less than 45 days old, the majority of calves originated from small farms (85.9\%). The pathogen that most frequently occurred was Cryptosporidium spp. (61.5\%) followed by rotavirus (56.4\%). The frequency of animal admission to ICU and GI pathogen identification was higher during the winter season (44.9\%) when compared to other seasons. Most calves included in the study were 1-6 days old (44.9\%). Lastly, co-infection with rotavirus and Cryptosporidium spp. occurred more frequently than other dual or multi-infection events. This study was the first to define severe diarrhea-causing GI pathogens from ICU admitted newborn calves in Turkey.
\end{abstract}

Keywords: Cryptosporidium spp.; coronavirus; E. coli ETEC K99+; rotavirus; newborn calf diarrhea; neonatal calf diarrhea; intensive care unit; ICU; emergency unit; animal hospital

\section{Introduction}

Calf mortality is one of the most frequently reported problems related with GI pathogens such as bacteria, viruses, and parasites [1,2]. Moreover, many studies have been conducted to investigate the relation between GI pathogens and newborn calf diarrhea (NCD). Diarrhea has been reported in $19.1 \%$ of dairy herds in Dutch farms with 
the highest frequency $(24.0 \%)$ in calves aged 1-21 days old [3-5]. Cryptosporidium spp. ( $>85 \%$ is C. parvum), bovine coronaviruses (BCoV), enterotoxigenic Escherichia coli K99/F5 (ETEC K99+), and bovine rotavirus are the most frequently identified GI pathogens from calves less than 30 days of age [6-8], reported with a prevalence of $17.7-79.9 \%$ for coronavirus, $27.8-63.0 \%$ for C. parvum, $2.6-45.1 \%$ for E. coli, and $17.7-79.9 \%$ for rotavirus [3]. Pathogen-induced diarrhea can occur in calves at different ages depending on the pathogen, but it is most often reported in calves $<1$ month old [9]. Cryptosporidium spp. are most often reported in calves 7-14 days old, coronaviruses in calves 4-30 days old, E. coli in calves 1-4 days old, and rotavirus in calves 4-14 days old [10]. It appears that age is the risk factor for infection with different GI pathogens. The season has also been predicted as a risk factor for diarrhea outbreaks [11,12]. Management may also be a reason for scours and mortality. It was later found that the occurrence levels of NCD was most likely associated with birth season [5].

Rotaviruses, classified under the Reoviridae family, are found to be primary causative pathogens for gastroenteritis in both animal and human infections [13,14]. Newborn calves are exposed to rotavirus by the consumption of contaminated milk, water, or feces. Rotavirus can cause damage to enterocytes in the intestine resulting in diarrhea [15]. Rotaviruses also create a potent risk for human health due to its zoonotic potential [15]. Regarding the enteric mucosal cell targeting viral pathogens, $\mathrm{BCoV}$ have been commonly identified from newborn calves aged up to 6 weeks, and it is known as a causative viral pathogen of winter dysentery or respiratory complex manifestation among adult cattle herds [16-18]. The mode of transmission of $\mathrm{BCoV}$ is usually a fecal-oral route, but fecalnasal or nasal-nasal routes are also possible [19]. The protozoan parasite, Cryptosporidium spp., is one of the most common parasites in newly delivered calves [20]. Cryptosporidium infection can easily spread in herds by infectious oocysts excreted in feces. Some Cryptosporidium species are known to be zoonotic. Humans are usually infected via contaminated food or water sources [21-23]. In immunocompromised individuals, infection with Cryptosporidium often results in GI-associated symptoms. Cryptosporidium can also infect immunocompetent individuals and cause self-limiting diseases. However, the infection can become chronic in immunocompromised individuals [24-27]. In a study from a farm in Maryland, USA, they observed that among the four Cryptosporidium species typically infecting cattle, only C. parvum was related to calf diarrhea [28]. In a study by Dubreuil et al. [29], enterotoxigenic E. coli (ETEC) was frequently isolated from calves within the first days of life. ETEC bacterial strains produce an adhesion molecule, a fimbriae antigen called $\mathrm{K} 99+$, also known as F5, on their surface and attach to small intestine epithelial cells. This leads to an increase in the motility of the lumen by causing the hypersecretion of mucous from the surrounding mucosal epithelial cells in response to secreted toxins from bacteria, thus increasing the severity of the disease [29,30]. Most of the ETEC strains do not secrete these types of toxins but instead secrete K99-expressing ETEC pathotypes, which are identified in neonatal diarrheic calves commonly associated with Sta type heat-labile enterotoxin and considered for neonatal diarrhea [29]. ETEC invades the GI system by the oral route when newborns are exposed to contaminated environments [29].

The aim of this study was to determine the seasonal and age-associated pathogen distribution of severe diarrhea in newborn calves $<45$ days old admitted to the ICU of Erciyes University animal hospital for a year. We also investigated the co-infection status of calves since co-infections might be affecting the severity of infection.

\section{Material and Methods}

\subsection{Calves and Sampling}

Sample collection was carried out from October 2016 to September 2017 from calves admitted to the emergency unit of the animal hospital at Erciyes University, Turkey. The calves originated from privately owned farms. The size of the farms was noted as small $(\leq 50)$ or large $(\geq 50)$. Among the admitted calves, only those $<45$ days old with severe diarrhea and at least $24 \mathrm{~h}$ of ICU hospitalization were included in this study. Regarding 
the enteric pathogen distribution in age groups, newborn calves were divided into three groups (Figure S1a). Calves were considered diarrheic if feces were abnormally frequent, soft and watery consistency and had bad odor. Clinical scoring and evaluations of disease severity were indexed according to skin test $(\geq 4 \mathrm{~s})$, an inability to stand, sunken eyes, and an inability to eat or drink [31]. ICU admission criteria, including tremors and a rectal temperature below $38.4{ }^{\circ} \mathrm{C}$, were defined by veterinary surgeons specialized in animal internal medicine.

Front-line check-up data and patient information were recorded in a university-owned animal hospital online patient database system (ERUVetO; V.15042019/2015, Kayseri, Turkey) upon registration to the emergency unit of the animal hospital. This system allowed us to retrospectively access further patient information such as date of birth and admission time. Fecal materials were freshly collected from the rectum of diarrheic calves just before starting medication or treatment. Collected samples were stored at $-80^{\circ} \mathrm{C}$ upon arrival to the diagnostic virology laboratory and were not kept longer than 6 months for genomic material and pathogen isolation studies.

\section{Ethics Statement}

This study was conducted in accordance with the Declaration of Helsinki, the ARRIVE guidelines, and approved by the committee of the Local Ethics Committee for Animal Experiments office (HADYEK) of Erciyes University and adhered to grant number TOA2017-7162 with 16/055 release code.

\subsection{Isolation of Viral RNAs and Molecular Viral Screening from Samples}

RNA isolation was performed on stool samples for the investigation of both rotavirus and coronavirus. To perform RNA isolation, a phenol-chloroform protocol was performed. Frozen fecal samples were thawed at room temperature for $30 \mathrm{~min}$ and turned upside down several times. Feces were diluted 1:10; w:vol with PBS buffer. After mixing samples by vortex homogenization, they were centrifuged at $10,000 \times g$ at $4{ }^{\circ} \mathrm{C}$ for $10 \mathrm{~min}$. To precipitate the total RNAs including viral genomic strands, RNA isolation was performed as described by Chomczynski et al. [32].

For the identification of rotavirus, one-step RT-PCR was used to target the VP6 region of isolated RNA by mixing $10 \mu \mathrm{L}$ of RNA with $40 \mu \mathrm{L}$ of one-step PCR master-mix (TransGen Biotech, Beijing, China). Primer pairs used are listed in Table 1, and previously described by Gómara et al. [33]. The reaction mixture was incubated at $50^{\circ} \mathrm{C}$ for $10 \mathrm{~min}$; subsequently, thermal cycle conditions were performed as follows: denaturation at $95^{\circ} \mathrm{C}$ for $15 \mathrm{~s}$, annealing at $55^{\circ} \mathrm{C}$ for $30 \mathrm{~s}$, and an extension step at $72^{\circ} \mathrm{C}$ for $30 \mathrm{~s}$. PCR conditions were completed after 35 cycles of the thermal loop. Initial denaturation at $95^{\circ} \mathrm{C}$ for $4 \mathrm{~min}$ and a final extension at $72{ }^{\circ} \mathrm{C}$ for $7 \mathrm{~min}$ were applied before and after heat cycles, and samples were cooled down to $4{ }^{\circ} \mathrm{C}$ at the final step. To amplify the bovine coronavirus $\mathrm{N}$ region from the RNA samples, one-step RT-PCR was performed on the RNA samples with BCoVF and BCoVR primer pairs (Table 1) and described previously by Cho et al. [34]. Thermal cycle conditions to identify the coronavirus were applied as described above for rotavirus, except the annealing step was performed at $62{ }^{\circ} \mathrm{C}$. 
Table 1. The detailed descriptions of primers for calf diarrhea PCR screening panels.

\begin{tabular}{|c|c|c|c|c|c|}
\hline Pathogen & Primer & Target-Loci & Sequence $\left(5^{\prime}-3^{\prime}\right)$ & Size (bp) & Ref. \\
\hline \multirow{2}{*}{ coronavirus } & BCoVF & \multirow{2}{*}{$\mathrm{N}$} & GCAATCCAGTAGTAGAGCGT & \multirow{2}{*}{730} & \multirow{2}{*}{ Cho et al. [34] } \\
\hline & BCoVR & & CTTAGTGGCATCCTTGCCAA & & \\
\hline \multirow{4}{*}{$\begin{array}{l}\text { Cryptosporidium } \\
\text { spp. }\end{array}$} & 18SiCF2 & \multirow{4}{*}{ SSU rRNA } & GACATATCATTCAAGTTTCTGACC & \multirow{2}{*}{763} & \multirow{4}{*}{ Ryan et al. [35] } \\
\hline & 18SiCR2 & & CTGAAGGAGTAAGGAACAACC & & \\
\hline & 18SiCF1 & & CСTATCAGCTTTAGACGGTAGG & \multirow{2}{*}{587} & \\
\hline & 18SiCR1 & & TCTAAGAATTTCACСTCTGACTG & & \\
\hline \multirow{2}{*}{ E. coli $\mathrm{K99+}$} & K99F & \multirow{2}{*}{ F5 } & TATTATCTTAGGTGGTATGG & \multirow{2}{*}{314} & \multirow{2}{*}{ Shams et al. [30] } \\
\hline & K99R & & GGTATCCTTTAGCAGCAGTATTTC & & \\
\hline \multirow{2}{*}{ rotavirus } & $157-\mathrm{R}$ & \multirow{2}{*}{ VP6 } & GTTTTCCAAGAGTDATHAHYTCAGC & \multirow{2}{*}{405} & \multirow{2}{*}{ Iturriza et al. [33] } \\
\hline & VP6-F & & GACGGVGCRACTACATGGT & & \\
\hline
\end{tabular}

\subsection{Genomic DNA Extraction from Stool Samples for the Screening of ETEC K99+ and Cryptosporidium spp.}

Genomic DNA extraction was performed on PBS-diluted stool sample $(n=78)$ supernatants. Briefly, collected fecal specimens were thawed at room temperature (RT) and mixed with PBS (1:10; w:vol). An alkaline phenol DNA extraction method was applied to all samples for DNA isolation for both E. coli K99+ (F5) and Cryptosporidium spp. screening with minor modifications [35]. Fecal samples were settled at RT for 10 min without centrifugation. To obtain Cryptosporidium spp. DNA materials, $320 \mu \mathrm{L}$ of PBS-diluted fecal liquid was transferred to a centrifuge tube containing $80 \mu \mathrm{L}$ of lysis buffer $(50 \mathrm{mM}$ Tris- $\mathrm{HCl}$, $\mathrm{pH}$ 8.5; $1 \mathrm{mM}$ EDTA, $\mathrm{pH} 8 ; 0.5 \%$ SDS). Tubes were subjected to repeated freeze-thaw cycles in chilled ethanol and a $60^{\circ} \mathrm{C}$ water bath for $2 \mathrm{~min}$ in each cycle. After the disruption of the oocyst wall to release genomic DNA, chloroform/isoamyl alcohol and ethanol precipitation methods were performed as described by Tang et al. [36]. To identify E. coli infection, DNA was extracted from feces $(n=78)$ with chloroform/isoamyl alcohol following thawing and dilution in PBS, as previously described by Tang et al. [36]. Air-dried DNA pellets were dissolved in $35 \mu \mathrm{L}$ of DNase/RNase free water and stored at $-20{ }^{\circ} \mathrm{C}$ for further analysis. Small subunit (SSU) rRNA gene region-directed nested PCR was applied to DNA samples for the confirmation of Cryptosporidium spp. 18SiCF2 and 18SiCR2 primer pairs used for first round amplification (Table 1). The second-round PCR was performed on the first amplified DNA templates along with $18 \mathrm{SiCF} 1$ and $18 \mathrm{SiCR} 1$ primer pairs (Table 1). Cryptosporidium spp. gene elongation and the DNA amplification protocol were applied as described by Ryan et al. [35]. To detect K99+, a master PCR mix solution targeting the F5 region was prepared as follows: 1XTaq buffer, $0.4 \mathrm{mM} \mathrm{MgCl} 2,5 \mathrm{mM}$ dNTP, $1 \mathrm{U}$ Taq DNA polymerase (Promega), $1 \mathrm{mM} \mathrm{K99F}$, and $1 \mathrm{mM}$ K99R primers (Table 1) were mixed to a final $20 \mu \mathrm{L}$ working volume [30].

\subsection{Isolation of Viral Pathogens in Cell Cultures}

MA-104 cell (ATCC, CRL-2378.1) culture was used for rotavirus isolation and virus propagation studies $[37,38]$. Cells were maintained with $10 \%$ fetal bovine sera-FBS (SIGMA, F0926) and 1X antibiotic (Sigma, A5955) containing M199 (Gibco, 11150059) culture growth media conditions. Fecal samples found positive for rotavirus by PCR were diluted 10 times (1:10, vol:vol) with PBS and centrifuged at $10,000 \times g$ for $10 \mathrm{~min}$ at $4{ }^{\circ} \mathrm{C}$. The supernatants were filter-sterilized through $0.22 \mu \mathrm{m}$ syringe filters (Millipore, SLGVM33RS) to eliminate bacterial and parasitic contaminations. For the activation of rotavirus, trypsin $(10 \mu \mathrm{g} / \mathrm{mL})$ (SIGMA, T1426) was added to filtrates, and samples were pre-incubated at $37^{\circ} \mathrm{C}$ on a heat block for $30 \mathrm{~min}$. Trypsin-activated samples were diluted (1:10) in M199 media. A cell monolayer of a MA104 cell line on a 24-well plate was inoculated with trypsin-treated inocula and replicated twice for each. A culture medium was replaced, and virus cultivation 
in cells was carried out until cytopathic effects (CPE) appeared microscopically up to day 3 of infection. For the isolation of coronavirus from fecal materials, a similar isolation method based on the rotavirus isolation method was applied with minor modifications [39]. MDBK cells were maintained with 10\% FBS containing DMEM-F12 (SIGMA, D2906) and FBS concentration was reduced to $1 \%$ during the $\mathrm{BCoV}$ isolations. The blind virus passages were performed until CPE appeared microscopically. Virus isolations were confirmed by one-step RT-PCR after phenol-chloroform RNA isolation from cell freeze-thawed cells which is described as before by Chomczynski et al. [32].

\subsection{Isolation of E. coli from Fecal Samples and Colony Screening}

E. coli isolations were performed on F5-positive samples. Fecal materials were diluted 10-fold in PBS (w:vol; 1:10) and further diluted (Log10) in liquid Luria-Bertani (LB) broth (vol:vol; 1:0) w/o antibiotics (Sigma, Neustadt, Germany). Dilutions were carried out by serially starting from $10^{-1}$ to $10^{-11}$. To enrich the bacterial numbers, tubes were incubated on a horizontal shaker at $37^{\circ} \mathrm{C}$ for $30 \mathrm{~min}$. The solid LB agar media was prepared without an antibiotic mixture, with the supplementation of sheep whole blood (5\%) for colony pick-up isolation [40]. Petri dishes were incubated at $37^{\circ} \mathrm{C}$ for 2 days to obtain bacterial colonies. A PCR screening method was performed for E. coli K99+ variant according to Francis et al. [40] and Güler et al. [41]. Visible colonies were applied to the colony screening procedure to confirm the isolation of ETEC K99+.

\subsection{Statistical Analysis}

Graphical illustrations and statistical analysis were performed with Graph Pad Prism 7 software (Graph Pad Software Inc., San Diego, CA, USA). The chi-square (and Fisher's exact) test was applied to the data to define the p-values of risk factors on the prevalence of each pathogen. Calculations of frequencies and percentages were done in Excel 2016 (Microsoft Excel Software, version 2016, Redmond, WA, USA) through tabular data formulations. A Venn diagram was constructed with online open access software (UGent, Genomics, \& 927, 2020).

\section{Results}

\subsection{Study Population and Inclusion to Study}

During the one-year study period, 78 calves out of 882 calves admitted to the animal hospital met the inclusion criteria and were included in the study. All 78 calves were admitted to the ICU for $24-48 \mathrm{~h}$. Most calves $(85.9 \%)$ in the ICU originated from small farms and the distribution of bovine species included Simmental (73\%), Holstein (15.4\%), and Brown Swiss (10.3\%), among others (1.3\%; cross-breed). Most calves included in the study were males $(65.4 \%)$. The number of calves admitted each month is shown in Figure 1. 


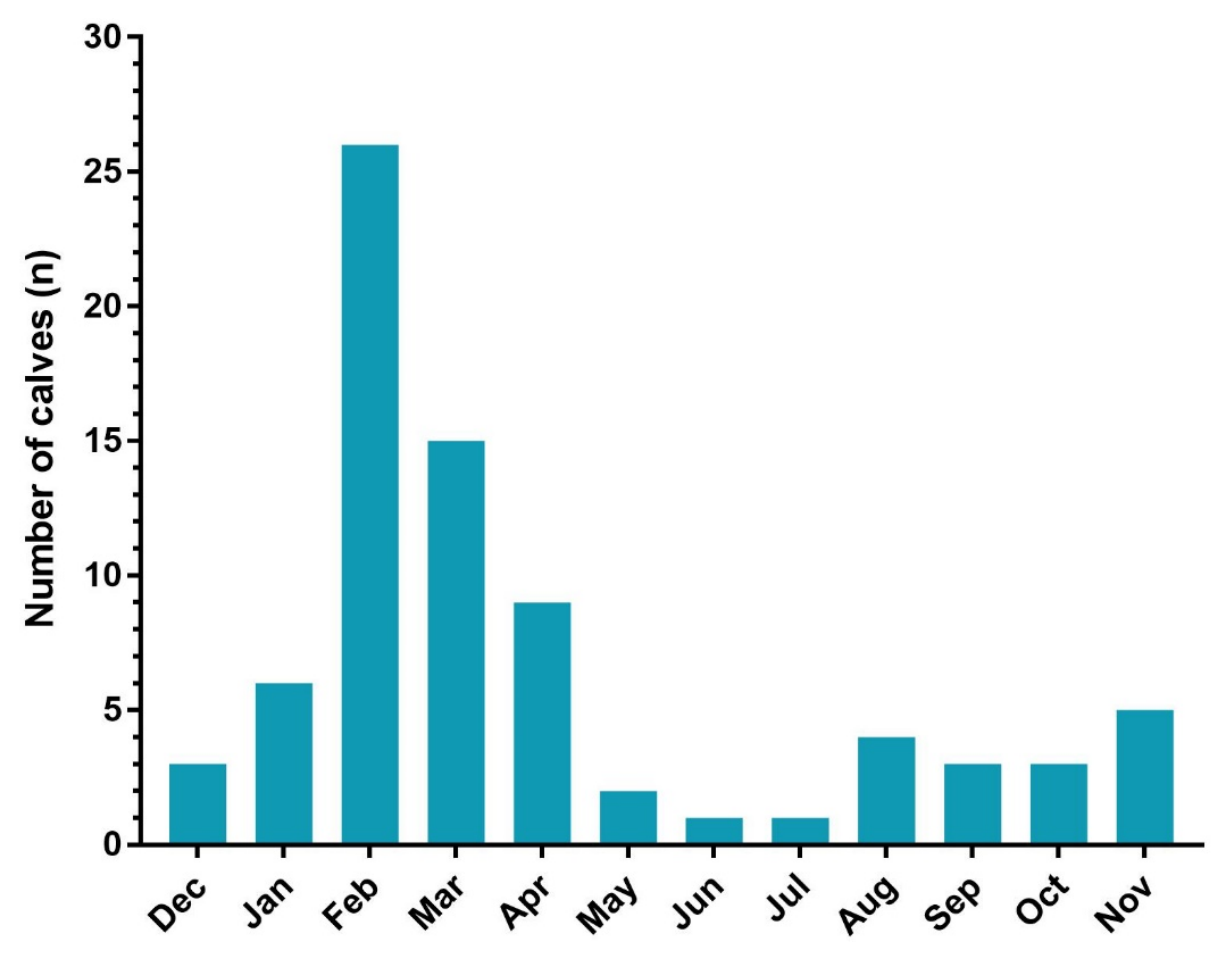

Figure 1. The figure presents the number of calves admitted to ICU and included in the study each month.

\subsection{Identified Diarrheal Pathogens}

All calves tested positive by molecular screening for at least one of the four examined pathogens. Molecular identification on isolated RNAs from feces revealed that $56.4 \%$ of samples tested positive for bovine rotavirus and $19.2 \%$ of calves were positive for coronavirus (Table 2). Molecular identification on isolated DNA from feces revealed that $15.4 \%$ of the calves were positive for ETEC K99+ and 61.5\% positive for Cryptosporidium spp. (Table 2). Molecular screening showed that Cryptosporidium spp. was the most identified pathogen followed by rotavirus (Table 2).

\subsection{Causative Agent Isolation Studies}

To understand the infectious stage of diarrhea, we performed the cell culture isolation for viruses and agar isolation method for ETEC K99+. We selected single-infected specimens for this purpose to eliminate the possibility that pathogens could interact and affect each other's growth and possible isolation. Cell cultures on 15 samples were identified as single-infected with rotavirus by RT-PCR (Table 2) which resulted in 13 rotavirus isolates in MA-104 cells (Figure 2a,b). Virus isolations were confirmed with amplification of the rotavirus VP6 gene by RT-PCR. We also performed MDBK cell cultures for feces from all three BCoV single-infected samples (Table 2), whereof two showed CPE in cell cultures (Figure 2c,d). BCoV isolations were further confirmed with the amplification of the $\mathrm{N}$ gene of genomic RNAs by PCR. LB agar cultures on seven fecal samples identified as singleinfected with ETEC K99+ by PCR (Table 2) resulted in four ETEC K99+ isolates (Figure 2e). The isolation of ETEC K99+ strains was confirmed by PCR directed to the F5 gene region of K99+ fimbria antigen. The isolation level of viral pathogens in cell culture (coronavirus, $66.7 \%$; rotavirus, $86.7 \%$ ) and bacterial colony isolation in agar (ETEC K99+ bacterial growth, $57.1 \%$ ), when compared to PCR findings, indicated that rotavirus; coronavirus; and ETEC $\mathrm{K} 99+$ pathogens were still infectious during hospitalization and ICU admission. Isolation studies also indicate that infectious rotavirus shedding is highly excrete $(86.7 \%$ isolation rate) during acute diarrhea in severe clinical cases while the infectious nature of ETEC $\mathrm{K} 99+$ and $\mathrm{BCoV}$ reduced in severe cases when calves admitted to ICU. 
Table 2. Diarrhea-causing pathogens identified by PCR in feces sample from calves admitted to ICU by age groups, season, and infection status (single, dual, or multi-infections).

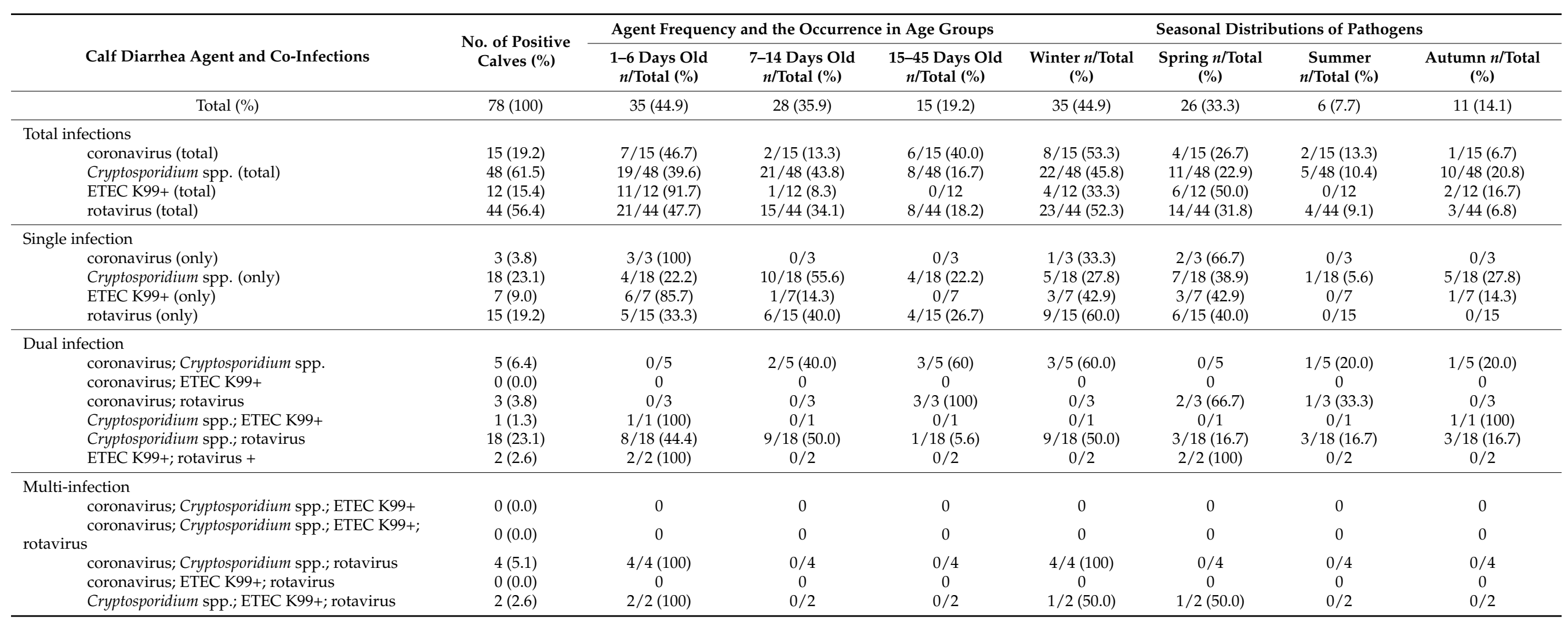



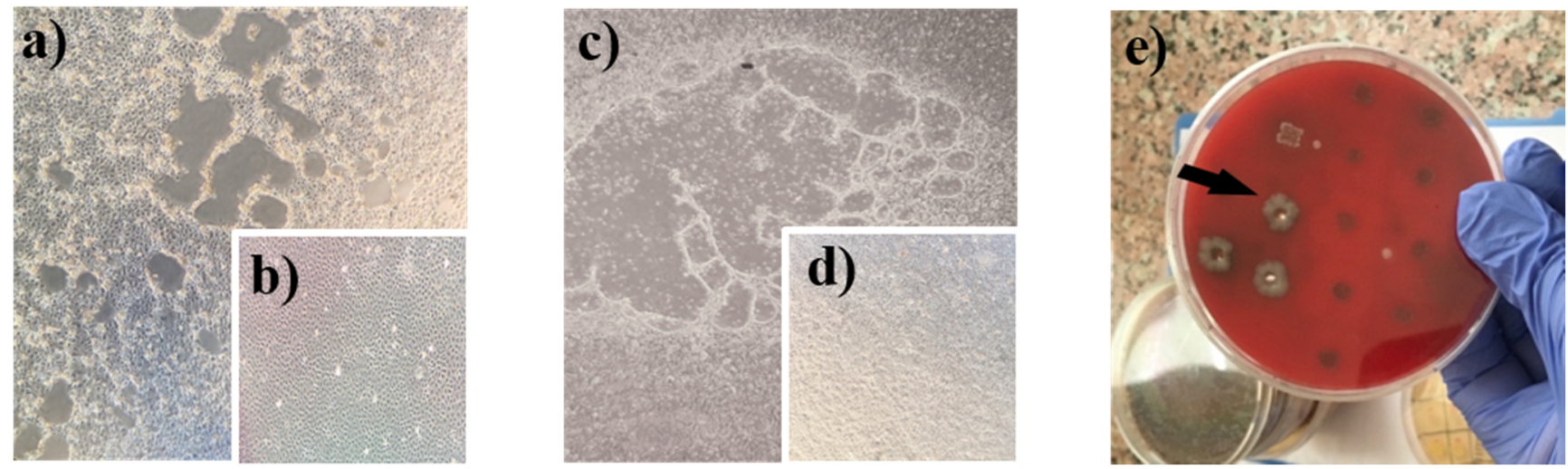

Figure 2. Isolation of infectious diarrheal pathogens from clinical samples. Bovine rotavirus caused the CPE on MA-104 cell monolayers (a) and mock-infected cells were intact (b). Coronavirus-induced CPE on MDBK cells (c) when compared to the mock-infected monolayer (d). The black arrow shows the colony picked ETEC K99+ on the solid blood agar dish (e).

\subsection{Risk Factor Analysis and Epidemiological Relevance}

The seasonal distributions of calves included in the study are listed in Table 2. Distribution of enteric pathogens in months and seasonal frequencies of pathogens (Figure 3) were also analyzed.

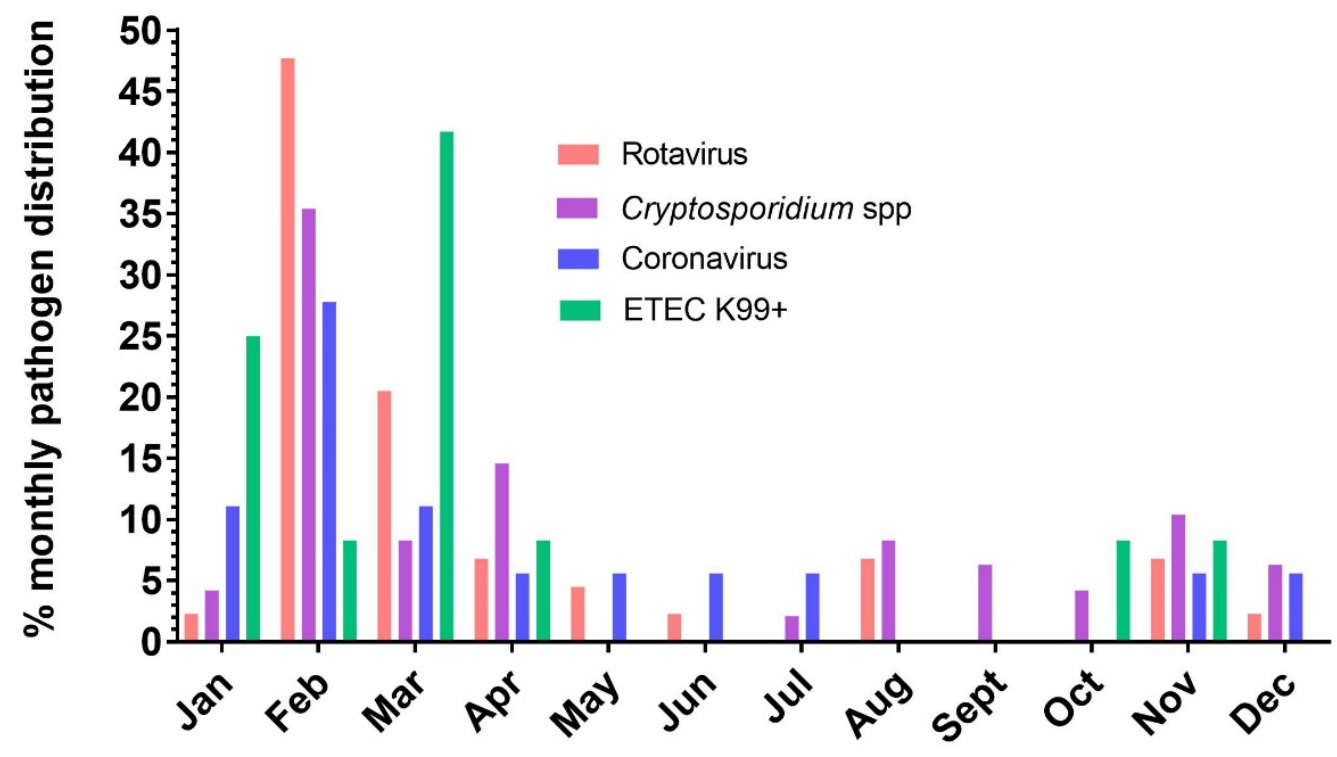

Figure 3. Bar chart: the percentage monthly distribution of pathogens excreted by neonatal calves with diarrhea admitted to the ICU.

Pathogen distribution analysis revealed that more calves ( $n=35$; age $<45$ days old) were admitted to the ICU with diarrhea during the winter season compared to other seasons (Table 2). Results indicated that the majority of enteric pathogens were mostly identified during the winter season, from December to February, except for ETEC K99+. Half of the identified ETEC K99+ was found during the spring season, from March to May (50\%), and subsequently most of the remaining ETEC K99+ was identified during the winter season (33.3\%). The detailed results are assembled in Table 2. Although most calves were admitted to the ICU with diarrhea in the winter months $(44.9 \%)$, most ETEC positive calves appeared during spring ( 6 calves $/ 12$ positive) (Table 2). Rotavirus, coronavirus, and Cryptosporidium spp. occurred in all four seasons. The Cryptosporidium seasonal infection rate is significantly 
different with the highest infection rate in autumn $(10 / 11 ; 90.9 \%)$ (Table S1), followed by summer $(5 / 6 ; 83.3 \%)$. The infection rate did not depend on the season for the other three pathogens (Table S1).

Among the admitted calves with severe diarrhea, most were $1-6$ days old $(n=35)$. Severe diarrhea admissions were reduced in the 7-14-day-old group $(n=28)$ and decreased by more than $50 \%$ (2.3-fold) in the 15-45-day-old group $(n=15)$. Rotavirus and Cryptosporidium spp. distribution in the 1-6-day-old group was estimated close to one another (60 and 54.3\%, respectively) and it was measured higher than coronavirus and ETEC K99+ (20 and 31.4\%, respectively). No animal in the 15-45-day-old group tested positive for ETEC K99+ (Figure S1a; Table S1), while the ETEC K99+ infection rate was significantly higher $(31.4 \%)$ in the $1-6$-day-old calves than in the $7-14$-days-old calves $(3.6 \%)$. The coronavirus infection rate was significantly higher in calves 15-45-day-old (40.0\%) than for calves in the other age groups (Table S1). The single, dual, or multi-infection statuses of calves were evaluated and are presented in Table 2 and in a Venn diagram (Figure S1b) to illustrate the distribution of identified pathogens along with the sample size. Among the examined calves, 55.1\% (43/78) were infected with a single pathogen, $37.2 \%(29 / 78)$ were infected with two pathogens, and $7.7 \%$ (6/78) were infected with multiple pathogens (Figure S1c). The distribution of pathogens as single, dual, or multi-infection along with the seasonal and age-related distribution of pathogen excretion is summarized in Table S1 along with the p-value estimated by chi-square analysis. The mode of infection of each pathogen reveals that the interaction of pathogens in a single and dual infection mode was more common for all tested enteric pathogens (Figure S1c; Table S1). We did not identify more than three enteric pathogens from the same calve (Figure S1b, Table 2). The most frequent co-infection was the dual infection with Cryptosporidium and rotavirus (Table 2). In fact, Cryptosporidium appears more often in co-infection $(50.0 \%)$ than as a single infection $(37.5 \%)$ (Table S1).

\section{Discussion}

A major economic cost in agriculture is the loss of newborn calves (USD 1.293 per pre-weaned calf as of 2019 estimation) [42]. The most severe NCDs frequently result in high mortality ratios, even if supportive treatments are administered $[3,10]$. It has been estimated that calf loss was $15.4 \%$ in Turkey due to diarrhea [43]. The frequency and distribution of diarrheal pathogens have been largely investigated and reported in field or farm-collected samples but not in the ICUs of animal hospitals [44,45]. We investigated the occurrence and frequency of common diarrhea-causing pathogens in newborn calves admitted to ICU of Erciyes University from October 2016 to September 2017 in relation to seasonal and age factors. We also investigated whether infections occurred in a single or concurrent manner.

We noticed that $85.9 \%$ of calves in the ICU largely originated from small farms. Small farms in the region mostly perform traditional farm activities, and calves are co-housed with their mother or other counterparts in the barns. A recent study in Turkey (2016) showed that more calves $(25.2 \%)$ from traditional farms had diarrhea than from large farms $(10 \%)$ [42]. NCD tends to be the biggest problem among small farms in the region of our study $(85.9 \%)$ when compared to large farms $(14.1 \%)$. Most diarrheal cases in traditional farming are due to unhygienic practices, poor management, and inadequate treatments. However, we could not evaluate farms for housing conditions, as this study was not conducted at farms. It is also significant that rearing calves individually can decrease diarrheal calves, and such rearing is often practiced by large-scale farm owners (records in the ERUVetO in this study). Another study has shown that bovine rotaviruses and coronaviruses are more often observed in group-housing systems compared with individual housing systems [46]. Individual housing systems are not common in small farms most likely due to their costs.

Our results indicated that males have higher ICU admissions than females (65.4 vs. $34.65 \%$ ). Species and gender were evaluated as risk factors for newborn diarrhea by 
Monney et al. [47], and they showed that males are more prone to diarrhea (61.38\%) than females (38.62\%). Regarding gender differences, Uhde et al. [48] did not find a correlation between genders and calve diarrhea (male, $48.3 \%$ vs. females, $51.7 \%$ ). This is also evidenced in a study by Çitil et al. [49] from the northeast part of Turkey. Çitil et al. [49] also indicated that there was a higher diarrhea incidence in the local bovine breed strain (38\%), followed by Simmental $(29.9 \%)$. We speculated that farmers mostly prefer to breed Simmental cow species for their meat products since the price of meat is higher than that of dairy milk products (based on personal communications with farmers). We did not evaluate either bovine species or sex distribution as a risk factor in this study because there was no homogeneous distribution among them.

The most frequent NCD-causing pathogen in the ICU in our study was Cryptosporidium spp. (61.5\%). Yildirim et al. [50] investigated the Cryptosporidium species distribution in Turkey which also included the same region that the calves originated from in this study. Results showed that $70.8 \%$ isolates were C. parvum. Moreover, C. parvum was the dominant species in pre-weaned calves, especially those with diarrhea [50]. Cryptosporidium spp. occurrence was around $20 \%$ in a study conducted by Içen et al. [51] in the 2-40-day-old diarrheic calves in the Southeastern Region of Anatolia in Turkey. Uhde et al. [48] estimated that Cryptosporidium spp. was the second most frequent $(41.7 \%)$ diarrhea pathogen in Switzerland, but its statistical importance was equal to that of rotavirus occurrence (55.8\%). The reason for the high Cryptosporidium spp. (61.5\%) occurrence in our study could be related with screened calves' population, as they originated from ICUs and suffered from severe diarrhea infection. Uhde et al. [48] and some others preferred the use of staining methods or immunochromatographic test kits in their studies. Rotavirus distribution among newborn diarrheic calves was estimated at 55\% in Israel [52], 42.7\% in Spain [53], and $42 \%$ in UK [54]. Altuğ et al. [55] shared the results of an occurrence study on calves aged less than 30 days old in Eastern Anatolia, and they estimated rotavirus occurrence at around $21.56 \%$ using lateral flow immunochromatographic test kits. We estimated rotavirus occurrence $(56.4 \%)$ as the second most frequently identified diarrhea-causing pathogen in calves from our study. The distribution of pathogens can vary among regions. This could be related to differences in herd management and calf rearing practices. Moreover, our study population originated from an ICU with calves critically ill with NCD. BCoV and ETEC K99+ occurrence was 19.2 and 15.4\% in this study, respectively. Içen et al. [51] reported BCoV (2.1\%) and ETEC K99+ (9.4\%) incidences, but results were much lower than in our findings. This could be because of incidences of diarrheal pathogens were more prevalent in severe calves. High occurrence obtained in the present study might also be due to the sensitivity of the diagnostic techniques used.

Brenner et al. [52] reported that the highest occurrence of diarrhea pathogens occurred during winter months. Colder seasons or lower temperatures may be optimal for pathogen survival and infectivity, especially for some viruses. Seasonal factors were retrospectively investigated in pediatric diarrhea in children at the ICU level for up to three years by Chao et al. [56]. The results showed that season was closely related to frequency rates of diarrheal pathogens. They also reported that rotavirus was more prevalent in cold months in the winter season, Cryptosporidium spp. often increased after the rainy season, and ETEC strains were higher during the summer season in pediatric hospitalized children [56]. Our results showed that during the winter season, more calves $<45$ days old $(44.9 \%)$ were admitted to the ICU with diarrhea compared to other seasons. The outbreak of bacterial diarrhea infections that also involve ETEC, also known as summer diarrhea, was increased in pediatric children in warmer weather [57]. In contrast to children, the ETEC occurrence in newborn calves has been reported at low levels during summer [52]. The reason could be that the management of animals that protects neonates from GI pathogens is more challenging at the herd level in colder seasons compared to warmer weather. Most bacterial infections are seen in human communities in the summer season because of the limited access to fresh and clean water sources. It was reported in Tanzania that inadequate hygienic conditions and storage practices are the source of the enteric pathogens during 
the summer [58]. However, in the present study, highest admission rates during the winter could be related to calving management systems that farmers are using in the region.

Çitil et al. [49] stated that the highest diarrhea occurrence rates during the winter could be due to the breeding strategies of the farmers. Çitil et al. [49] also speculated that bacterial infections such as E. coli occur in newly delivered calves due to exposure to nonhygienic environments immediately after the delivery. This could be related to co-housing the calves with others in small farms. However, further investigations should be addressed to independently identify weather and temperature factors in terms of transmission and persistence around and in livestock communities. However, it remains unknown from this study whether the calving season is a risk factor or not.

The first week of neonatal age was found to be highly significant for newborn diarrheal calves by Demir et al. [42] in the northeast region of Turkey. Similarly, Çitil et al. [49] also reported that 1-7 days old of neonatal age was highly significant and that NCD frequency dropped in the following days. In the present study, the same trend was observed, as most calves included in the study were 1-6 days old (44.9\%) and all had diarrhea. Demir et al. [42] reported that enteritis-associated calf death mostly occurred (72.7\%) within 1-6 days after delivery. In our study, calves 1-6-day-old group were almost exclusively infected with ETEC. This is consistent with the results reported by Demir et al. [42] who demonstrated that enteritis-associated calf death mostly occurred (72.7\%) in 1-6-day-old calves [42]. However, the calves in our study were all alive. As for ETEC, most 1-6-day-old calves (47.7\%) were found infected with rotavirus in our study, closely followed by the 7-14-day-old calves (34.1\%). This was also observed for rotavirus by Içen et al. [51], as they observed that $66.5 \%$ of calves $<10$ days old became infected. Cryptosporidium spp. infection most frequently occurred in the 7-14-day-old (43.8\%) calves in our study. However, the infection rate in the 1-6-day-old calves was almost similar (39.6\%). Similarly to our findings, Santín et al. [28] reported the highest Cryptosporidium spp. prevalence $(66.7 \%)$ in calves at 2 week of ages.

Severe diarrhea in newborns is often associated with concurrent infections. Rotavirus occurred more often as dual infection with Cryptosporidium spp. than other dual infection modes $(23.1 \%)$ in the present study. The highest single infection status of newborn calves was reported in calves infected with C. parvum (28.6\%) by Uhde et al. [48] in Switzerland. Içen et al. [51] indicated that the highest single-infected calves were estimated in rotavirus-infected $(25 \%)$ calves. The occurrence level of the same pathogen in different infection modes (single, dual, or multi-infection) remained unknown. We found that ETEC K99+ primarily occurred as a single infection, however, the incidence of single infection was found to be higher (58.3\%) than other infection modes being tested. Cryptosporidium spp. and rotavirus occurrence were found higher (23.1\%) in dual infection modes, $50 \%$ and $52.3 \%$, respectively. The higher distribution of rotaviruses with Cryptosporidium spp. with dual infection in the 1-6-day-old (44.4\%) and 7-14-day-old (50\%) groups (Table 2) is considered an important finding in this study. Uhde et al. [48] reported that dual infection of $C$. parvum with rotavirus reached up to $19.0 \%$, and this was estimated at $15.6 \%$ by Içen et al. [51]. Our findings indicate that the occurrence of a single infection of Cryptosporidium spp. (23.1\%) or dual infection with rotavirus $(23.1 \%)$ in the ICU was similar. Cruvinel et al. [59] also estimated the occurrence of rotavirus and Cryptosporidium in a dual infection mode, and results indicate that rotavirus and Cryptosporidium occurrence is correlated to the occurrence levels of each individually, and this correlation is a risk factor for NCD. Furthermore, rotavirus and Cryptosporidium infection were positively correlated with coronavirus in a multi-infection mode [59]. In the present study, the occurrence of coronavirus was mostly identified in the dual infection mode (53.3\%) and it was estimated to be higher with Cryptosporidium spp. (6.4\%) than rotavirus (3.8\%), similarly to what was reported by Cruvinel et al. [59]. We found that the coronavirus occurrence level was higher than those in the findings of Gumusova et al. [60] (1.96\%), Uhde et al. [48] (2\%), Içen et al. [51] (1\%), and Cruvinel et al. [59] (7.2\%). We estimated the total occurrence of coronavirus in the ICU was $19.2 \%$ but remained low in the single infection $(3.8 \%)$ and 
dual infection cases with rotavirus (3.8\%). However, we did not investigate the correlation matrix of these pathogens. In addition, we could not detect coronavirus when neonates become infected with ETEC K99+ and vice versa. Such differences could show that BCoV plays a role in a different stage of NCD. Medina et al. [61] indicated that the viral shedding of rotaviruses decreased 5-6 days after the onset of diarrhea and mortality is more likely associated with the co-infection status of calves. Similarly, our isolation findings indicate that rotavirus is the responsible causative agent in the development of severe acute diarrhea in the ICU, according to the high positivity rate in PCR and isolation success $(86.7 \%)$ in cell culture. It is also highlighted by Medina et al. [61] that BCoV rapidly replicates in intestinal epithelial cells and causes mass villus loss in the mucosal surface of the lumen more rapidly (40-90 h) after infection. Severe symptoms more likely appear when the virus has disappeared from the GI mucosal surface. The high success of isolation rate (66.7\%) and low level of virus positivity in PCR analysis could be related with this rapid and sudden virus replication due to a massive loss of infected villus. This could explain why calves develop severe NCD in the late acute phase of coronavirus infection with a lower positivity rate in both PCR and cell culture isolation studies. The colony isolation rate of ETEC K99+ remained at $57.1 \%$ where all isolates were obtained from 1-4-day-old calves. This rapid severe development could be related with antigenic type of ETEC K99+ and number of E. coli bacteria ingested. Unfortunately, we did not perform E. coli characterization studies. It must be highlighted in this study that rotaviruses and Cryptosporidium spp. have a strong correlation that interact in dual infections in newborn neonates aged up to 15 days old (94.4\% in a summary of 1-6- and 7-14-day-old calves). These events mainly occurred during the winter season. Farmers engaged in herd management on especially small farms should consider shifting their calving season to a less prevalent season, such as summer and autumn, and proper hygienic practices should be frequently employed while calving occurs. Such practices might include controlling bacterial ETEC transmissions among the animals. Furthermore, few small farms (36\%) perform vaccination programs against NCD in the region (ERUVetO records).

\section{Conclusions}

We conclude, due to the high number of admissions to the ICU of an animal hospital during the winter and spring, that the winter season is a risk factor for severe NCD calves. The first week of neonatal age is significant in terms of infection with ETEC K99+. There is also a close relation between rotavirus and Cryptosporidium spp. occurrence in a dual infection manner, and this frequently occurred in the first two weeks of neonatal age, especially in the 7-14-day-old group, which is important for Cryptosporidium infection. Future direction could include a higher number of calves during several years of investigation to reveal of the importance of acute infections, age, and seasonal impact, which could lead to an understanding of disease prognosis and pathogen correlations.

Supplementary Materials: The following are available online at https://www.mdpi.com/article/ 10.3390 /vetsci8070128/s1, Figure S1. Representation of age distributions of identified pathogens from respective age groups, Table S1. Chi-square test results for the determination of several risk factors of newborn diarrhea in the ICU.

Author Contributions: Conceptualization, E.B., N.Ç., İ.S. and İ.K.; data curation, E.B.; funding acquisition, İ.S.; investigation, E.B., E.S., N.S., S.K. and E.A.; methodology, İ.K., A.G.G., E.B. and İ.S.; project administration, İ.K. and İ.S.; resources, İ.K. and A.G.G.; software, E.B., G.E. and S.K.; supervision, I.K. and A.G.G.; validation, E.B. and P.A.; visualization, E.B. and G.E.; writing-original draft, E.B., G.E. and İ.K.; writing—review editing, E.B., İ.K., G.E., N.Ç. and E.S. All authors have read and agreed to the published version of the manuscript.

Funding: This research was funded by the office of BAP-Scientific Research Foundation Council of Erciyes University (TOA-2017-7162).

Institutional Review Board Statement: The study was conducted according to the guidelines of the committee of Local Ethics Committee for Animal Experiments office, (HADYEK), of Erciyes 
University and adhered to grant number TOA-2017-7162 with 16/055 release code. This study was conducted in accordance with the Declaration of Helsinki, ARRIVE guidelines.

Informed Consent Statement: Not applicable.

Data Availability Statement: No new data were created or analyzed in this study. Data sharing is not applicable to this article.

Acknowledgments: We are grateful to the faculty and staff members of the Animal Hospital Emergency Unit and Department of Internal Medicine of Erciyes University for their cooperation and countless contributions to this study. We also would like to address our great appreciation of the undergraduate and graduate students who were enrolled in the clinical rotations in the animal hospital emergency unit during the 2016-2017 period for the sampling and documentation of patient IDs. We would like to thank to reviewers for constructive comments, and suggestions and especially for their valuable time to improve the manuscript with their critiques.

Conflicts of Interest: The authors declare no conflict of interest. The present affiliations that are mentioned in the author list had no role in the design of the study; in the collection, analyses, or interpretation of data; in the writing of the manuscript; or in the decision to publish the results.

\section{References}

1. Van Metre, D.C.; Tennant, B.C.; Whitlock, R.H. Infectious Diseases of the Gastrointestinal Tract. In Rebhun's Diseases of Dairy Cattle, 2nd ed.; Thomas, J.D., Simon, F.P., Eds.; Saunders ELSEVIER: Saint Louis, MO, USA, 2008; pp. 200-294. [CrossRef]

2. Cho, Y.-I.; Yoon, K.-J. An overview of calf diarrhea-infectious etiology, diagnosis, and intervention. J. Vet. Sci. 2014, 15, 1-17. [CrossRef]

3. Meganck, V.; Hoflack, G.; Opsomer, G. Advances in prevention and therapy of neonatal dairy calf diarrhoea: A systematical review with emphasis on colostrum management and fluid therapy. Acta Vet. Scand. 2014, 56, 75. [CrossRef]

4. Perez, E.; Noordhuizen, J.P.T.M.; van Wuijkhuise, L.A.; Stassen, E.N. Management factors related to calf morbidity and mortality rates. Livest. Prod. Sci. 1990, 25, 79-93. [CrossRef]

5. Bartels, C.J.M.; Holzhauer, M.; Jorritsma, R.; Swart, W.A.J.M.; Lam, T.J.G.M. Prevalence, prediction and risk factors of enteropathogens in normal and non-normal faeces of young Dutch dairy calves. Prev. Vet. Med. 2010, 93, 162-169. [CrossRef] [PubMed]

6. Nydam, D.V.; Mohammed, H.O. Quantitative risk assessment of Cryptosporidium species infection in dairy calves. J. Dairy Sci. 2005, 88, 3932-3943. [CrossRef]

7. Timurkan, M.Ö.; Alkan, F. Identification of rotavirus A strains in small ruminants: First detection of G8P [1] genotypes in sheep in Turkey. Arch. Virol. 2020, 165, 425-431. [CrossRef]

8. Gomez, D.E.; Arroyo, L.G.; Poljak, Z.; Viel, L.; Weese, J.S. Detection of bovine coronavirus in healthy and diarrheic dairy calves. J. Vet. Intern. Med. 2017, 31, 1884-1891. [CrossRef] [PubMed]

9. Windeyer, M.C.; Leslie, K.E.; Godden, S.M.; Hodgins, D.C.; Lissemore, K.D.; LeBlanc, S.J. Factors associated with morbidity, mortality, and growth of dairy heifer calves up to 3 months of age. Prev. Vet. Med. 2014, 113, 231-240. [CrossRef]

10. Naylor, J.M. Neonatal Calf Diarrhea. In Food Animal Practice, 5th ed.; Anderson, D.E., Rings, D.M., Eds.; W.B. Saunders ELSEVIER: Saint Louis, MO, USA, 2009; pp. 70-77. [CrossRef]

11. Waltner-Toews, D.; Martin, S.W.; Meek, A.H. Dairy calf management, morbidity and mortality in Ontario Holstein herds. II. Age and seasonal patterns. Prev. Vet. Med. 1986, 4, 125-135. [CrossRef]

12. Martin, S.W.; Schwabe, C.W.; Franti, C.E. Dairy calf mortality rate: Influence of meteorologic factors on calf mortality rate in Tulare County, California. Am. J. Vet. Res. 1975, 36, 1105-1109.

13. Kumar, A.; Charpilienne, A.; Cohen, J. Nucleotide sequence of the gene encoding for the RNA binding protein (VP2) of RF bovine rotavirus. Nucleic Acids Res. 1989, 17, 2126. [CrossRef]

14. Matthijnssens, J.; Ciarlet, M.; Heiman, E.; Arijs, I.; Delbeke, T.; McDonald, S.M.; Palombo, E.A.; Iturriza-Gómara, M.; Maes, P.; Patton, J.T.; et al. Full genome-based classification of rotaviruses reveals a common origin between human Wa-Like and porcine rotavirus strains and human DS-1-like and bovine rotavirus strains. J. Virol. 2008, 82, 3204-3219. [CrossRef]

15. Dhama, K.; Chauhan, R.S.; Mahendran, M.; Malik, S.V.S. Rotavirus diarrhea in bovines and other domestic animals. Vet. Res. Commun. 2009, 33, 1-23. [CrossRef] [PubMed]

16. Boileau, M.J.; Kapil, S. Bovine coronavirus associated syndromes. Vet. Clin. N. Am. Food. Anim. Pract. 2010, 26, 123-146. [CrossRef] [PubMed]

17. Oma, V.S.; Tråvén, M.; Alenius, S.; Myrmel, M.; Stokstad, M. Bovine coronavirus in naturally and experimentally exposed calves; viral shedding and the potential for transmission. Virol. J. 2016, 13, 100. [CrossRef]

18. Mebus, C.A.; Stair, E.L.; Rhodes, M.B.; Twiehaus, M.J. Pathology of neonatal calf diarrhea induced by a coronavirus-like agent. Vet. Pathol. 1973, 10, 45-64. [CrossRef] [PubMed]

19. Thomas, C.J.; Hoet, A.E.; Sreevatsan, S.; Wittum, T.E.; Briggs, R.E.; Duff, G.C.; Saif, L.J. Transmission of bovine coronavirus and serologic responses in feedlot calves under field conditions. Am. J. Vet. Res. 2006, 67, 1412-1420. [CrossRef] [PubMed] 
20. Trotz-Williams, L.A.; Wayne Martin, S.; Leslie, K.E.; Duffield, T.; Nydam, D.V.; Peregrine, A.S. Calf-level risk factors for neonatal diarrhea and shedding of Cryptosporidium parvum in Ontario dairy calves. Prev. Vet. Med. 2007, 82, 12-28. [CrossRef] [PubMed]

21. Feltus, D.C.; Giddings, C.W.; Schneck, B.L.; Monson, T.; Warshauer, D.; McEvoy, J.M. Evidence supporting zoonotic transmission of Cryptosporidium spp. in Wisconsin. J. Clin. Microbiol. 2006, 44, 4303-4308. [CrossRef] [PubMed]

22. Graczyk, T.K.; Fayer, R.; Cranfield, M.R. Zoonotic transmission of Cryptosporidium parvum: Implications for water-borne cryptosporidiosis. Parasitol. Today 1997, 13, 348-351. [CrossRef]

23. Razakandrainibe, R.; Diawara, E.H.I.; Costa, D.; Le Goff, L.; Lemeteil, D.; Ballet, J.J.; Gargala, G.; Favennec, L. Common occurrence of Cryptosporidium hominis in asymptomatic and symptomatic calves in France. PLoS Negl. Trop. Dis. 2018, 12, e0006355. [CrossRef] [PubMed]

24. Hunter, P.R.; Nichols, G. Epidemiology and clinical features of Cryptosporidium infection in immunocompromised patients. Clin. Microbiol. Rev. 2002, 15, 145-154. [CrossRef] [PubMed]

25. Semenza, J.C.; Nichols, G. Cryptosporidiosis surveillance and water-borne outbreaks in Europe. Eurosurveillance 2007, 12, 121-123. [CrossRef]

26. Ryan, U.; Zahedi, A.; Paparini, A. Cryptosporidium in humans and animals-A one health approach to prophylaxis. Parasite Immunol. 2016, 38, 535-547. [CrossRef]

27. Xiao, L.; Morgan, U.M.; Fayer, R.; Thompson, R.C.A.; Lal, A.A. Cryptosporidium systematics and implications for public health. Parasitol. Today 2000, 16, 287-292. [CrossRef]

28. Santín, M.; Trout, J.M.; Xiao, L.; Zhou, L.; Greiner, E.; Fayer, R. Prevalence and age-related variation of Cryptosporidium species and genotypes in dairy calves. Vet. Parasitol. 2004, 122, 103-117. [CrossRef]

29. Dubreuil, J.D.; Isaacson, R.E.; Schifferli, D.M. Animal enterotoxigenic Escherichia coli. EcoSal. Plus 2016, 7, 1-47. [CrossRef]

30. Shams, Z.; Tahamtan, Y.; Pourbakhsh, A.; Hosseiny, M.H.; Kargar, M.; Hayati, M. Detection of enterotoxigenic K99 (F5) and F41 from fecal sample of calves by molecular and serological methods. Comp. Clin. Path. 2012, 21, 475-478. [CrossRef] [PubMed]

31. Wattiaux, M.A. Neonatal diarrhoea. In Heifer Raising-Birth to Weaning; University of Wisconsin-Medison, Babcock Institute for International Dairy and Development: Madison, WI, USA, 2005; pp. 121-124.

32. Chomczynski, P.; Sacchi, N. The single-step method of RNA isolation by acid guanidinium thiocyanate-phenol-chloroform extraction: Twenty-something years on. Nat. Protoc. 2006, 1, 581-585. [CrossRef] [PubMed]

33. Iturriza Gómara, M.; Wong, C.; Blome, S.; Desselberger, U.; Gray, J. Molecular characterization of VP6 genes of human rotavirus isolates: Correlation of genogroups with subgroups and evidence of independent segregation. J. Virol. 2002, 76, 6596. [CrossRef]

34. Cho, K.-O.; Hoet, A.E.; Loerch, S.C.; Wittum, T.E.; Saif, L.J. Evaluation of concurrent shedding of bovine coronavirus via the respiratory tract and enteric route in feedlot cattle. Am. J. Vet. Res. 2001, 62, 1436-1441. [CrossRef]

35. Ryan, U.; Xiao, L.; Read, C.; Zhou, L.; Lal, A.A.; Pavlasek, I. Identification of novel Cryptosporidium genotypes from the Czech Republic. Appl. Environ. Microbiol. 2003, 69, 4302-4307. [CrossRef]

36. Tang, J.-n.; Zeng, Z.-g.; Wang, H.-n.; Yang, T.; Zhang, P.-j.; Li, Y.-l.; Zhang, A.-y.; Fan, W.-q.; Zhang, Y.; Yang, X.; et al. An effective method for isolation of DNA from pig faeces and comparison of five different methods. J. Microbiol. Methods 2008, 75, 432-436. [CrossRef] [PubMed]

37. Arnold, M.; Patton, J.T.; McDonald, S.M. Culturing, storage, and quantification of rotaviruses. Curr. Protoc. Microbiol. 2009, 15, 15C-3. [CrossRef] [PubMed]

38. Wyatt, R.; James, W.; Bohl, E.; Theil, K.; Saif, L.; Kalica, A.; Greenberg, H.; Kapikian, A.; Chanock, R. Human rotavirus type 2: Cultivation in vitro. Science 1980, 207, 189-191. [CrossRef] [PubMed]

39. Saif, L.J.; Heckert, R.A.; Miller, K.L.; Tarek, M.M. Cell culture propagation of bovine coronavirus. J. Tissue Cult. Methods 1988, 11, 139-145. [CrossRef]

40. Francis, D.H.; Remmers, G.A.; DeZeeuw, P.S. Production of K88, K99, and 987P antigens by Escherichia coli cultured on synthetic and complex media. J. Clin. Microbiol. 1982, 15, 181-183. [CrossRef]

41. Güler, L.; Gündüz, K.; Ok, Ü. Virulence factors and antimicrobial susceptibility of Escherichia coli isolated from calves in Turkey. Zoonoses Public Health 2008, 55, 249-257. [CrossRef]

42. Demir, P.A.; Aydin, E.; Ayvazoglu, C. Estimation of the economic losses related to calf mortalities Kars province in Turkey. Vet. Fak. Derg. 2019, 3, 283-290.

43. Günlü, A. Buzağı Kayıpları ve Buzağı Hastalıklarının Ekonomik Değerlendirmesi. In Buzaği Să̆liği ve Yetiştiriciliği, 1st ed.; Erdem, H., Çiftci, E., Işik, K., Yorgancilar, Ü., Cevdet, Y., Eds.; Medisan: Istanbul, Turkey, 2020; pp. 64-65.

44. Renaud, D.L.; Rot, C.; Marshall, J.; Steele, M.A. The effect of Cryptosporidium parvum, rotavirus, and coronavirus infection on the health and performance of male dairy calves. J. Dairy Sci. 2021, 104, 2151-2163. [CrossRef]

45. Benito, A.A.; Monteagudo, L.V.; Arnal, J.L.; Baselga, C.; Quílez, J. Occurrence and genetic diversity of rotavirus A in faeces of diarrheic calves submitted to a veterinary laboratory in Spain. Prev. Vet. Med. 2020, 185, 105196. [CrossRef] [PubMed]

46. Bertoni, E.A.; Bok, M.; Vega, C.; Martinez, G.M.; Cimino, R.; Parreño, V. Influence of individual or group housing of newborn calves on rotavirus and coronavirus infection during the first 2 months of life. Trop. Anim. Health Prod. 2021, 53, 62. [CrossRef] [PubMed]

47. Monney, J.D.; Adjogoua, E.V.; Karamoko, Y.; Akran, A. Incidences of calf diarrhea and the associated risk factors in ivory coast (2015-2017). IJAVMS 2020, 19, 454-461. [CrossRef] 
48. Uhde, F.L.; Kaufmann, T.; Sager, H.; Albini, S.; Zanoni, R.; Schelling, E.; Meylan, M. Prevalence of four enteropathogens in the faeces of young diarrhoeic dairy calves in Switzerland. Vet. Rec. 2008, 163, 362-366. [CrossRef] [PubMed]

49. Çitil, M.; Gunes, V.; Karademir, B. 1996-2001 yılları arasında KAÜ Veteriner Fakültesi İç Hastalıkları Kliniğine getirilen ishalli buzağılar üzerine retrospektif bir çalışma. Vet. Fak. Derg. 2003, 9, 39-42.

50. Yildirim, A.; Adanir, R.; Inci, A.; Yukari, B.A.; Duzlu, O.; Onder, Z.; Ciloglu, A.; Simsek, E. Prevalence and genotyping of bovine Cryptosporidium species in the Mediterranean and Central Anatolia region of Turkey. Comp. Immunol. Microbiol. Infect. Dis. 2020, 69, 101425. [CrossRef]

51. Içen, H.; Arserim, N.B.; IŞIK, N.; Özkan, C.; Kaya, A. Prevalence of four enteropathogens with immunochromatographic rapid test in the feces of diarrheic calves in east and southeast of Turkey. Pak. Vet. J. 2013, 33, 496-499.

52. Brenner, J.; Elad, D.; Markovics, A.; Grinberg, A.; Trainin, Z. Epidemiological study of neonatal calf diarrhoea in Israel-A one-year survey of faecal samples. Isr. J. Vet. Med. 1993, 48, 113.

53. García, A.; Ruiz-Santa-Quiteria, J.A.; Orden, J.A.; Cid, D.; Sanz, R.; Gómez-Bautista, M.; de la Fuente, R. Rotavirus and concurrent infections with other enteropathogens in neonatal diarrheic dairy calves in Spain. Comp. Immunol. Microbiol. Infect. Dis. 2000, 23, 175-183. [CrossRef]

54. Reynolds, D.J.; Morgan, J.H.; Chanter, N.; Jones, P.W.; Bridger, J.C.; Debney, T.G.; Bunch, K.J. Microbiology of calf diarrhoea in southern Britain. Vet. Rec. 1986, 119, 34-39. [CrossRef]

55. Altuğ, N.; Yüksek, N.; Özkan, C.; Keleş, I.; Başbuğan, Y.; Agaoglu, Z.T.; Kaya, A.; Akgul, Y. Rapid etiological diagnosis of neonatal calf diarrhoea with immunochromatographi test kits. Van Vet. J. 2013, 24, 123-128.

56. Chao, D.L.; Roose, A.; Roh, M.; Kotloff, K.L.; Proctor, J.L. The seasonality of diarrheal pathogens: A retrospective study of seven sites over three years. PLoS Negl. Trop. Dis. 2019, 13, e0007211. [CrossRef] [PubMed]

57. Paredes-Paredes, M.; Okhuysen, P.C.; Flores, J.; Mohamed, J.A.; Padda, R.S.; Gonzalez-Estrada, A.; Haley, C.A.; Carlin, L.G.; Nair P.; DuPont, H.L. Seasonality of diarrheagenic Escherichia coli pathotypes in the US students acquiring diarrhea in Mexico. J. Travel Med. 2011, 18, 121-125. [CrossRef] [PubMed]

58. Mattioli, M.C.; Boehm, A.B.; Davis, J.; Harris, A.R.; Mrisho, M.; Pickering, A.J. Enteric pathogens in stored drinking water and on caregiver's hands in tanzanian households with and without reported cases of child diarrhea. PLoS ONE 2014, 9, e84939. [CrossRef]

59. Cruvinel, L.B.; Ayres, H.; Zapa, D.M.B.; Nicaretta, J.E.; Couto, L.F.M.; Heller, L.M.; Bastos, T.S.A.; Cruz, B.C.; Soares, V.E.; Teixeira, W.F.; et al. Prevalence and risk factors for agents causing diarrhea (coronavirus, rotavirus, Cryptosporidium spp., Eimeria spp., and nematodes helminthes) according to age in dairy calves from Brazil. Trop. Anim. Health Prod. 2020, 52, 777-791. [CrossRef] [PubMed]

60. Gumusova, S.O.; Yazici, Z.; Albayrak, H.; Meral, Y. Rotavirus and coronavirus prevalence in healthy calves and calves with diarrhea. Medycnya Weterinaria 2007, 63, 62-64.

61. Torres-Medina, A.; Schlafer, D.H.; Mebus, C.A. Rotaviral and coronaviral diarrhea. Vet. Clin. N. Am. Food Anim. Pract. 1985, 1, 471-493. [CrossRef] 